\title{
Debt revolts: Ecuadorian foreclosed families at the PAH in Barcelona
}

\author{
Maka Suarez ${ }^{1}$ (D)
}

Published online: 23 August 2017

(C) The Author(s) 2017. This article is an open access publication

\begin{abstract}
Can present day grassroots direct actions be considered revolutionary? In this paper, I argue that seemingly "reformist" demands can be considered revolutionary in today's neoliberal capitalism. At the turn of the twenty-first century, working class Ecuadorian migrants in Barcelona were trying to join the global middle classes via subprime mortgage loans and despite their precarious jobs. Following the collapse of Spain's housing bubble, unemployed, defaulting on their mortgages, and risking home eviction, they turned to housing activism. They joined the Platform for People Affected by Mortgages (PAH) and became daily protestors for the right to housing and against indebtedness. Looking at PAH approaches that encouraged debt default among low-income families, strategies to reconvert repossessed homes by rescued banks into social housing units, or the effective occupation of buildings that belonged to these banks by the PAH to house evicted families, I claim that these moments represent revolutionary instances of a broader fight against indebtedness taking place globally which can be considered - as many did at the PAH — a fight against capitalism at large. In this paper I illustrate how people who had seldom participated in social mobilization became part of a small Barcelonan movement for the right to housing that grew exponentially throughout Spain succeeding in canceling thousands of mortgage debts and stopping equally as many evictions. PAH's spaces of encounter and action made possible a cross-class alliance upheld by weekly assemblies and near daily direct actions against financial institutions and a proausterity central government. These moments demonstrate the ability of everyday people to reclaim housing, redefine the narrative of indebtedness, and - in the case of Barcelona - it even made possible taking control of City Hall.
\end{abstract}

Keywords Debt default · Labor migration · Social movements · Mortgaged homes · Spanish recession $\cdot$ Financial crisis resistance $\cdot \mathrm{PAH}$

Maka Suarez

m.suarez@gold.ac.uk

1 Goldsmiths, University of London, London, UK 
"The morality of debt and the morality of work are the most powerful ideological weapons in the hands of those running the current system. That's why they cling to them even as they are effectively destroying everything else. It's also why debt cancellation would make the perfect revolutionary demand.”(Graeber 2011a).

\section{Introduction}

By the late 1990s, working class Ecuadorians left their country after decades of structural adjustment policies had resulted in soaring inflation and a bankrupted financial system. As unemployment soared and savings dwindled following dollarization, hundreds of thousands sought economic refuge and new opportunities by migrating to Spain. A decade later, as Ecuadorian migrants were trying to join the global middle classes via subprime mortgage loans and despite their precarious jobs, they became part of Spain's own housing bubble and economic collapse. Following the burst of the bubble, they became unemployed - as many worked in construction and domestic services with unstable and insecure contracts - and were forced to default on their mortgage loans. Ecuadorians were not alone, thousands of Spaniards saw jobs disappear, and mortgage default quickly rose but the economic downfall disproportionately affected youth and migrant groups (García 2010). By 2016, more than 720,000 foreclosure processes had been initiated and over 500,000 home evictions had taken place since 2007. In 2016, this amounted to over 250 evictions per working day. ${ }^{1}$ Many of these families, including my Ecuadorian interlocutors, turned to housing activism as a measure of last resort. They joined the Platform for People Affected by Mortgages, the PAH for its Spanish acronym, ${ }^{2}$ and became daily protestors for the right to housing and against indebtedness.

What became evident in the lives of Ecuadorian PAH activists is a broader shift in present day neoliberal capitalism, one in which profits are made not only from labor exploitation but increasingly from novel forms of financial predation. These new forms of wealth extraction are made possible through specific debt instruments and the ability of financial power to profit from people's abilityand necessity - to incur debt. In the case of Ecuadorian migrant workers in Barcelona, buying a home in Spain was perceived as a form of upward mobility. It allowed migrant families to secure housing as well as other forms of wellbeing for them and their children in a context of rapid change and uncertainty. Many Ecuadorian migrants had managed to regularize their stay in Spain, and in their views they were in a good economic situation when they signed their mortgage loans between 2003 and 2007. However, the burst of the housing bubble evidenced the precarity of their contracts and the insecurity of their incomes. In addition, it revealed the volatile nature and adverse terms of their mortgage loans and the burdening consequences of defaulting on them.

The way in which debt default permeates through every aspect of Ecuadorian migrants' lives makes evident the need to examine the complex networks and relationships that make up subprime mortgage lending. As Bear et al. (2015) remind us, there is a growing need to question how capitalism is generated within changing life projects and how shifting categories of class, gender, kinship, and nation are the result of multiple historical encounters. This interrogation can already be witnessed in the growing literature in anthropology and the social sciences directly interested in understanding the intricate functioning of financial capitalism.

\footnotetext{
${ }^{1}$ Evictions do not take place on weekends or holidays. This data is available from Spain's General Council of the Judiciary. This number includes evictions resulting from rented and mortgaged properties.

2 The name in Spanish is Plataforma de Afectados por la Hipoteca
} 
From the technological affordances of financial markets and how they are designed and intertwined (Knorr-Cetina and Preda 2012; Wosnitzer 2016; Zaloom 2006), to the webs of people needed to sustain it (Ho 2009; Riles 2011), the past years have seen a booming academic production helping us make sense of the inner working of financial human and non-human actors. However, we know less about the ways in which sophisticated financial products impinge on the lives of working class families - often the most affected by these forms of financial profiting - and the ongoing forms of organizing and resisting that have sprung up. The case of the PAH illustrates how these practices of wealth extraction (Lee and Martin 2016; Meister 2016) are affecting the lives of everyday people but it also elucidates how new forms of resistance can be imagined (Appel 2014; Graeber 2011a).

In this paper, I argue that seemingly "reformist" demands can be considered revolutionary in today's neoliberal capitalism. I am interested in how the different methods and strategies used by PAH participants to face indebtedness can then be seen - as many people at the PAH did - as revolutionary. I take, on the one hand, the way in which PAH activists assessed their demands as revolutionary. On the other hand, I am also interested on how other groups of activists, like Ecuadorian migrant workers - who had little to no experience in social mobilization - came to see the PAH as a place for changing the narrative on debt and reimagining their futures after mortgage default. In thinking about revolutionary change, I follow David Graeber's commentary on Immanuel Wallerstein's view on revolutions nowadays. Graeber (2011b) asks, "Were revolutions ever really what we thought them to be? For me, the person who has asked this most effectively is the great world historian Immanuel Wallerstein. He argues that for the last quarter millennium or so, revolutions have consisted above all of planetwide transformations of political common sense." 3 I take current debt struggles in many parts of the world as a starting point for thinking about a new wave of transformations - even if not necessarily in sync with each other. There is, for instance, the Alt Banking group in New York City where detailed knowledge of financial instruments, its legislations, and the apparatus that sustains much of financial trading is being rethought in an attempt to democratize and reimagine finance (Appel 2014, 603; see also Ho 2012). There are also attempts to mobilize around debt abolition and default, like the Education Debtors Union (McClanahan 2011) or the various projects developed by the Strike the Debt collective to resist indebtedness (Strike Debt 2014). Others have posited on the possibilities of collective debt default to interrupt the cycle of capitalist accumulation as well as to bring together different leftist approaches to new economic possibilities (Clover 2011). In this light, then, PAH approaches that encouraged debt default among low-income families, the change of narrative on indebtedness achieved at PAH weekly assemblies, the call to reconvert repossessed homes by rescued banking institutions into social housing units, or the effective occupation of buildings that belonged to these banks by the PAH to house evicted families, represent instances of this fight against indebtedness and for many at the PAH against capitalism at large.

The ethnographic perspective I present in this essay also allows us to intimately understand how unemployment and mortgage default among Ecuadorian migrants in Barcelona intertwine

\footnotetext{
${ }^{3}$ I recognize there is a long-standing debate over what constitutes revolutionary practices and what does not going back to, at least, Marx's and Engels writings on revolution. At the time the growing divergence was between revolutionary change that would do away with the capitalist system and the growing Marxist inspired Social Democratic Party in the 1890s who came to be seen as reformists (Tucker 1978). This debate has been taken further in anthropological theory by various authors (Shah 2014; Smith 2016; Bloch 2010). In this essay, I attempt to move beyond the absolute of revolution - meaning an all or nothing debate - and question whether practices that challenge capitalist logics can be considered revolutionary in today's financial capitalism.
} 
with broader life projects of migration, care, and social mobility. It illustrates how people who had seldom participated in social mobilization became part of a small Barcelonan movement for the right to housing that grew exponentially throughout Spain succeeding in canceling thousands of mortgage debts and stopping equally as many evictions. By 2016, the PAH had over 240 chapters across Spain with thousands of people gathering weekly to talk about housing access and debt cancelation. In the first part of the article, I summarize how Ecuadorian migrants became involved in Spain's housing bubble and how massive default became a turning point in their aspirations for social upward mobility. I then show how PAH spaces of encounter and action made possible a cross-class alliance upheld by weekly assemblies and near daily direct actions against financial institutions and a pro-austerity central government. The final section looks at self-assessment by housing activists that claimed the PAH could become the starting point of a radically different way of thinking about housing access in the Barcelona region. These moments demonstrate the ability everyday people have to reclaim housing, redefine the narrative of indebtedness, and -in the case of Barcelona- it even made possible taking control of City Hall.

\section{Subprime families: the international working class in the Spanish housing bubble}

When Cristobal ${ }^{4}$ and Angelica signed a 260,000 euros loan for their $50 \mathrm{~m}^{2}$ flat back in 2005, they believed they were building a path for their children to succeed in Spain and a better life for themselves. Meant as a way for them to "move forward," as they would often put it, they saw private property as a way to shield children from the rough start they had experienced when they first arrived in Spain. This included fragile housing conditions, their encounter with racist landlords, and the instability attached to renting in Spain. This instability has its origin in a much longer history of private property in Spain that dates back to the second half of Franco's dictatorship. Back in the 1960s, in an effort to turn Spaniards into "proprietors" rather than "proletarians," housing was massively allocated on a private property regime through various public-private financing mechanisms (Laredo 2011). Cities, like Barcelona, had become overcrowded due to migration from poorer, rural areas of Spain. This had rapidly deteriorated living conditions on the city's outskirts where slum dwellers were quickly gathering. Franco's Ministry of Housing proposed to assign newly built, low quality housing, under a regime of private property to provide housing for low-income families while introducing new mechanisms of social control through debt repayment (Colau and Alemany 2012). In contrast to France or Germany where an equally large number of houses were built for social housing rentals, in Spain most new constructions were turned into privately own homes. Fifty years later, a new wave of low-income migrants from the global south would purchase these homes at inflated prices, in need of much repair, and through risky and expensive loans.

Thanks in part to government-sponsored regularization processes in 2000, 2001, and $2005^{5}$; family unification strategies became possible for Ecuadorian migrants often changing their original migratory expectations. They, in turn, became Spain's newest subjects of credit by transforming large amounts of remittances sent to their home country into mortgage loan payments in Spain between 2003 and 2007. The mortgages they were offered, however,

\footnotetext{
${ }^{4}$ All names are pseudonyms.

5 The 2001 legal process was an extension of the 2000 law (Tobes and Grijalba 2010).
} 
embodied the essence of subprimeness in Spain, a global phenomenon that consists in allocating second-rate mortgages among poor people (López and Rodríguez 2011; Maurer 1999). In Spain, like in the USA, "subprime lending hit low-income communities of color first, as residents who had once struggled with redlining and housing discrimination now faced widespread foreclosure" (Stout 2016, p. 161; see also Hernandez 2009; Jefferson 2013). In Spain too, migrant populations were able to access mortgage loans but on less beneficial terms (Diaz-Serrano and Raya 2014) and often by utilizing their social networks as a means to access - and pay for-expensive mortgage loans (Palomera 2014; Suarez 2017).

Cristobal and Angelica's subprime loan was for the full amount of their flat (nearly 245,000 euros), plus an added personal loan (15,000 euros on Cristobal's name) to cover all expenses associated with issuing their mortgage loan - including the realtor's commission, banking fees, and notary costs. The personal loan was included as a "special deal" to them, explained by the banking institution as an offer for refurbishing part of their flat, mainly kitchen and bathroom, which needed repair. What was not clearly explained to them at the time of signing was the high price of default and the volatility of their mortgage interest rate. In fact, they were told their monthly payments would be roughly the same each month with little increases over time. This was far from being true. Banks, on the other hand, had set up various mechanisms to assure themselves no limit to their profits, even in situations that could have been beneficial to borrowers. ${ }^{6}$ Ecuadorian migrants' subprime mortgage loans were, unlike low-cost prime lending, very expensive. They had higher upfront and continuing costs, a number of fees included in their loan, and numerous insurance policies - some of which they had no interest in acquiring but were added nonetheless. Their loans had varying interest rates and high default charges ${ }^{7}$; these rapidly changing interest rates meant their monthly payments could quickly swing - precisely the opposite of what banking institutions told them at the time of signing. Finally, their loan could be sold or transferred to a third party (securitized) without their knowledge or consent. Some of these loan conditions have been specifically described in the literature as the essence of subprime lending (Chomsisengphet and Pennington-Cross 2006). Furthermore, these credit and debt agreements, which have been proven illegal in certain cases, became a form of financial predation that translated into devastating real life consequences for Ecuadorian migrants when, as in Cristobal and Angelica's case, monthly payments suddenly went through the roof while employment dwindled.

The case of subprime lending among the Ecuadorian migrant community in Spain is similar to what happened in the USA where remittance flows were used to turn previously excluded groups into new subjects of credit. As Gary Dimsky $(2009,162)$ observes,

One magnet for banks was the astronomically-growing market for cross-border remittances, of which banks initially had a tiny share... So, racial exclusion - the refusal to make loans to minority credit-applicants - was partly replaced by extortionary racial inclusion - providing access to credit to those formerly excluded from it, but only at terms and conditions that are predatory, that is, which involve far higher costs and penalties for non-compliances than "normal" loans.

\footnotetext{
${ }^{6}$ Some of these unfair clauses included above-average interest rates and bank protections against super low interest rates that would have benefited mortgage holders lowering their monthly installments. Both of these legal clauses in Spain's current mortgage law have been determined to be unfair and illegal by the European Union Court of Justice in 2016 and again in 2017.

${ }^{7}$ Some of my interlocutors saw their default interest rate go as far up as $30 \%$. This was declared illegal by a European Union tribunal in 2016 and currently they cannot be above $12 \%$.
} 
In a similar manner, Spanish banks were willing to offer Ecuadorian migrants mortgage loans in Spain but under significantly different conditions. This resulted in many of my interlocutors decreasing (or fully stopping) their remittances to Ecuador after buying homes in Spain. It should be noted that much of the economic literature on Ecuadorian migration reminds us that in the late 1990s and early 2000s remittances accounted for the country's second largest source of gross domestic product (GDP) growth, only surpassed by oil exports (Alberto et al. 2005; Calero et al. 2009). Thus, the switch from remittances to mortgage payments involves large sums of transnational money flows. ${ }^{8}$

Although subprime lending redirected remittance resources from families in Ecuador to the banking system in Spain it also facilitated many family unification processes by making it easier to demonstrate adequate housing for incoming members. When Juan obtained his work permit in mid 2003 for instance, he learned he could bring his wife and three children from Ecuador to Spain through a family unification scheme. They had been apart since he had left in 2001. His unification application pushed him to look for a new home since he needed to demonstrate to immigration services proof of suitable accommodations for his family in Spain. He learned that buying a home through a mortgage would make things easier with immigration services since regulations for homeowners were much more lax. As he put it, "if you had a rental contract immigration would come check out your place, but if you owned the house they didn't come." A few months later, Juan moved into his $56 \mathrm{~m}^{2}$ home and his family arrived soon after. According to Juan, few times in his life he had felt more accomplished than when he welcomed his family into their Spanish home. Little did he know then that the mortgage loan agreement he and his guarantor had signed would turn into a financial whirlwind if one of them defaulted. ${ }^{9}$

Family unification is not the only way subprime lending links kinship and capitalism (Yanagisako 2013). Subprime loans were bought by my interlocutors with the idea of inheriting a home to their children in Spain. Before buying houses in Spain, Ecuadorian migrants used their savings to buy houses in Ecuador for their return. However, when they became subjects of subprime credit, many of them started reimagining their future. Some considered staying in Spain indefinitely, while others viewed their mortgages as an investment for their children, particularly if children decided to stay in Spain. That was the case of Raquel. She explained that, "the kids don't want to go back. They feel at home here [in Spain], so we thought that a property was the best thing we could do for them." Raquel was one of many Ecuadorians to frame their motivation to buy a house based on the wellbeing of their children. This aspiration, however, turned into a nightmare with the mortgage crisis. She was not alone in feeling this way. Antonio lost his wife 2 years before I arrived to the field. A mid-40s man with a construction job during the boom years, Antonio was requested by his bank manager to include his three children as "heirs" to his property after his wife's passing. When Antonio defaulted on his mortgage, his children became potential debtors

\footnotetext{
${ }^{8}$ It is also true that Ecuadorian migrants purchased homes in Ecuador before purchasing homes in Spain. Oftentimes income derived from renting out these first properties stayed with families in Ecuador and replaced remittances. These rents, however, were often lower than original remittances from Spain (Suarez 2017).

${ }^{9}$ Not uncommonly among my interlocutors a number of dubiously legal guaranteeing practices were undertaken where people became cross-guarantors, co-proprietors, or chain-guarantors without fully knowing the consequences of these legal arrangements. The consequences of tying kin and friendship networks to finance agreements were disastrous when any of them defaulted since all debtors and guarantors became responsible for the full amount of the debt (Suarez 2017).
} 
rather than future homeowners. This situation was possible because the Spanish mortgage legislation allows financial institutions to continue collecting on part of a mortgage debt even after the home has been foreclosed and repossessed. This effectively means that in Spain, the house is not the sole collateral to the mortgage loan, and people remain indebted for hundreds of thousands of euros even after the house is repossessed because the borrower - and their guarantors - have a personal and unlimited liability over the mortgage loan. Unlike in most Western legal systems, the liability for repayment does not stop on the mortgaged property, and the borrower and any guarantors can be pursued in case of default for the debt, any outstanding penalty interest charges, and court fees. They are responsible for the debt "with all present and future assets", and the debt does not expire nor can it be dismissed under personal bankruptcy. This is what legally allowed financial institutions in Spain to garner incredible power over indebted individuals, effectively creating new forms of debt peonage (similar to those produced by student debt in the USA).

In buying into Spain's housing bubble, Ecuadorian migrants took out large loans to buy overpriced properties in the city's fringes - poor neighborhoods characterized by their difficult accessibility and limited public investment. The mortgage loans they could access were plagued with volatile interest rates, unfair legal clauses, expensive upfront fees, insurance payments forced into the contracts, and the high cost-and limited explanation - of mortgage default. Though many of my interlocutors saw these credit regimes as affording them a path to social mobility through private property, it is clear now that it amounted to little more than another form of exploitation through financial predation. The subordinate conditions that accompanied their low-skilled positions were paired with subpar access to mortgage loans resulting in people in precarious forms of employment tied to novel means of financial wealth extraction under the complicit eye of state power. The instrumentality of the legal system in producing this form of financial predation was further made evident when hundreds of families defaulted on their mortgage loans and found themselves indebted for life even beyond home repossession.

Ecuadorian migrants who defaulted on their mortgage loans initially saw their default as a personal failure feeling ashamed of their inability to pay. The morality of debt repayment hid away the violence of a system based on financial predation that turned Ecuadorian migrants' remittances, social networks, and aspirations into expendable elements of financialization. The PAH became crucial for thousands of debt defaulters in Spain who faced a life of indebtedness and stigmatization as debtors. In their case, "debt cancellation would make the perfect revolutionary demand" (Graeber 2013).

\section{Becoming activists for the right to housing}

In May 2015, the former spokeswoman for the PAH, Ada Colau, became mayor of Barcelona. In her victory speech, Colau asserted that "it is the human quality of women and men at the PAH what has made it possible for me to be here today. It is the PAH that first demonstrated to us all that Yes, We Can [win] ... Thanks to the PAH we are here today." Ada Colau was one of the founders of the movement in 2009, and in 2014 she left the PAH to start her own political party and run for mayor of Barcelona. Her party, as she described it numerous times, took on many of the tools she had learned at the PAH-like women holding central roles in decision making spaces and building a collective agenda from below. Many of my Ecuadorian interlocutors voted for the first time in those elections feeling they were 
voting for "one of our own" as Monica, a 48-year old Ecuadorian woman, put it. In those elections, Ada Colau won in all but two districts in Barcelona, ${ }^{10}$ significantly increasing the number of people who turned out to vote in the city's poorest neighborhoods.

Monica met $\mathrm{Ada}^{11}$ when she first attended the PAH in 2009 after her brother Rafael defaulted on his mortgage loan and was about to be evicted from his flat. Monica was Rafael's guarantor and older sister and she felt partly responsible for him doing well in Spain. His default did not only put at risk her mortgaged home but also her sense of responsibility for her extended family. A neighbor had heard of the PAH and told Monica to go there in the odd chance they could help. "I didn't think anyone could help us," Monica said "but we were desperate. I sought help everywhere, I didn't care.” In her first meeting, Monica could not utter a word. She remembers a small group of people of about 20 (today they easily go above 100) and most attendees being Ecuadorian. "At the beginning it was mostly us [Ecuadorians], now look at how we've grown," she told me in one of our conversations. She recalled crying through most of her first assembly and Ada providing comfort. Monica sobbingly recounted her brother's ordeal and what she felt was a hopeless situation, but she quickly learned that things would be different after joining the PAH. A few weeks later, her brother's eviction was scheduled to take place. The activists she met promised her they would mobilize to stop it by physically standing in front of the door in order to prevent the judicial commission from delivering the eviction notice. Monica incredulously returned home. On that day, around 25 people showed up, most wearing green t-shirts, and one of them was carrying a megaphone. Contrary to Monica and her brother's beliefs the eviction was postpone for another month. Monica was instructed to keep coming to the PAH to learn how to negotiate a relief to her brother's debt, something they both thought impossible. The process took two more years to come to fruition but Monica became a PAH activist learning the legal workings of her brother and her own mortgage loan, and supporting many more people's fight against indebtedness. In her own words, "at the PAH I learn that yes, we can, [que si se puede], even when I thought nothing could be done anymore the PAH taught me differently. I will never forget this."

Monica's story is illustrative of what many of my Ecuadorian interlocutors learned at the $\mathrm{PAH}$, that by acting collectively they could find a viable solution to their debt by pressuring banks to forgive debts after repossession as well as to improve housing access for all. This was clearly articulated in a conversation with Manuel, a 43-year old Ecuadorian living in Spain for the past 13 years. He explained the relationship with banking officials since joining the PAH, "now, when they see us coming with our green t-shirts they quickly finish up what they're doing and they see us immediately. Before I would go and wait for hours. Now they know we are the PAH." He proudly retold this and many stories where his mortgage loan manager could no longer threaten him or his wife with taking away their children or having them deportedtwo intimidations he heard in the initial stages of his default. Marta, a 52-year old Ecuadorian woman in default for 4 months when I met her, had been particularly struck by her bank's manager remarks when he blatantly faulted her and her family of being "dumb, ignorant immigrants" for having taken out mortgages without knowing what they signed. After joining the PAH, she had gone back repeatedly, usually accompanied by a group of activists who, like her, were fed up with insults and mistreatments. Nearly all of my interlocutors reported a change in attitude when banking officials learned they were involved in the PAH. As Marta put

\footnotetext{
${ }^{10}$ Ada Colau only lost in the two richest districts of Barcelona.

${ }^{11}$ I refer to Ada Colau only as Ada in those instances where my interlocutors would have spoken about her in that familiar tone.
} 
it, expressing a common feeling among my interlocutors, "Now they respect us." The daily struggle of hundreds of newly formed housing activists in Barcelona allowed many of my Ecuadorian interlocutors to become debt free after foreclosure. By finding a debt solution, many of these families were able to liberate their guarantors from their debts. This was crucial in remaking social relationships that took a heavy toll during the foreclosure process. Perhaps the best place to begin to understand how this was possible is by looking at PAH assemblies and how they became spaces of encounter and transformation, providing a new narrative for indebtedness.

Assemblies were the lifeblood of the PAH. They were a communal learning space and not infrequently nearly 150 people attended them in Barcelona. Though initially migrant workers accounted for the largest number of foreclosed individuals, by the time I began my 2 years of fieldwork with the movement in 2012, the number of Spanish-born families in foreclosure had rapidly increased. ${ }^{12}$ The PAH quickly became a heterogeneous mix of people who would have rarely met elsewhere: construction and domestic laborers, young couples with children, selfemployed entrepreneurs who re-mortgaged their homes to start a business, or technical workers and early career professionals in entry-level positions who got fired due to the economic downturn. All arrived at the PAH with the same problem: mortgage default. The commonality of their indebtedness opened up a new and unexpected way in which all became equal as well as created an opportunity for re-thinking debt relations. The first place to attend was a "welcoming assembly." These meetings were meant for knowledge sharing, and they revolved around legal and practical information needed when facing mortgage default problems. A detailed explanation of the foreclosure and eviction process was laid out; a small green book was distributed free-of-charge with a step-by-step explanation, and questions and answers were taken at the end. These were volunteer-run spaces where knowledge was socialized giving everyone the necessary tools and legal expertise to face indebtedness and home eviction (see also Sabaté 2016). But assemblies also became a place where debt default was re-signified from a shameful situation into an opportunity to put forward democratic demands. Indebtedness was a binding mechanism that put a very diverse group of people on equal footing. The PAH taught attendees that the financial crisis was a large scale scam and that defaulting on a mortgage loan was not people's individual fault but a broader process in a system of economic dispossession. That growing unemployment, austerity measures, cuts to a thinning welfare state, and growing inequality, were all part of how capitalist accumulation worked. ${ }^{13}$

By transmitting this broader view of Spain's economic downturn as a "financial scam," the movement allowed people - and in fact encouraged people in difficult economic situationsto default on their mortgages and seek a viable solution. This often implied the loss of property but it also cleared families - and their guarantors - of all further debts. Families were also advised on how to negotiate a renting contract with the bank that foreclosed them in order to stay in their homes for a few more years paying a reduced rent. These assemblies provided

\footnotetext{
${ }^{12}$ I conducted 2 years of fieldwork with Ecuadorian migrant families in Barcelona who were defaulting on their mortgages. I spent a spell of 12 months from September 2012 to September 2013 at the PAH in Barcelona. I also spent 3 months in Ecuador interviewing and living with the families of my Barcelonan interlocutors from October to December 2013. I returned to Barcelona to conduct further fieldwork from May to September 2014 and from May to June 2015.

${ }^{13}$ It is worth mentioning here that the different ways in which capitalist ideologies were explained changed from one PAH to another, which also reflected the way in which different people within the movement understood $\mathrm{PAH}$ strategies as more or less revolutionary. I will return to this point in the next section.
} 
essential information on how to solve a concrete problem but they also expanded the political horizons of people who had rarely been part of a social movement. The PAH offered everyday people a space to deal with the growing dependency on credit instruments to make a living and access basic needs. PAH assemblies can be seen as a collective response to a broader capitalist project that turns debt into a means of livelihood for the poor and profit for the wealthy. A problem that is not unique to families in Barcelona. From US credit card holders (Williams 2004), South Africa's newly banked black customers (James 2014), or Chilean poor families that subsist on credit (Han 2012), we know debt has become indispensable for achieving any form of dignified life among the global working classes. What has become most relevant after 2008 is the existence of a global financial elite - particularly associated with Wall Street and other financial centers - that extracts a large part of the world's wealth at the expense of everyone else. Andrew Ross (2014) has referred to this as a creditocracy, and Maurizio Lazzarato (2012) reminds us that indebtedness is a mechanism of control at the heart of financial capitalism. These refined forms of profiting are no longer solely tied to labor exploitation but also to speculative capital and people's indebtedness. Furthermore, debts have become a form of survival for a large part of the population, putting them at great risk of default, while turning those same debts into another mechanism for wealth creation and power reproduction.

In the following section, I turn to narratives of change and action against indebtedness within and outside the PAH that point to the potential for revolutionary change that could arise from resisting debt as well as finding alternatives to housing access. I focus on selfassessments by long-term PAH activists that point to an understanding of PAH practices and methods that goes beyond a mere reformist understanding. My ethnography shows how the PAH is a relevant movement for thinking about new forms of resistance to financial capitalism and to debt in particular, as well as a present day example of successful self-organizing against housing speculation. The PAH is an anti-debt, anti-eviction movement that has created unequal momentum in Spain gathering people in the thousands to discuss the centrality of housing access against the neoliberal understanding of housing as a commodity. The PAH can teach us how to begin forming collectives that come together to unveil the violence of debt, resist its advancement in the lives of working class families, and build alternatives that create much needed solutions at this moment in history.

\section{Is this revolutionary change?}

In a 2-day workshop that brought together activists, academics, artists, leftist politicians, and other social thinkers, a member of the PAH intervened in a presentation on mobilization and revolution. Speaking about a citizen-led law proposal (an ILP for its Spanish acronym) supported by the PAH and other social actors in March 2011, ${ }^{14}$ he challenged the view that passing a law that sought to: make mortgaged properties the sole collateral to a defaulted loan, halt home evictions without adequate rehousing, and reconvert properties repossessed by banking institutions into social housing units for a period of at least 5 years, would have been a reformist measure. Pau Llonch, the PAH speaker that day and a self-identified anti-capitalistcommunist, argued that the measure would have effectively destroyed speculative housing markets by reconverting millions of empty properties into social housing (Llonch 2013). He

\footnotetext{
${ }^{14}$ In Spanish called an Iniciativa Legislativa Popular (ILP). It was initiated by the PAH, along with the Observatori DESC, UGT Catalunya, CCOO Catalunya, CONFAVC, UCC, and Taula del Tercer Sector.
} 
went further to admit that no one expected the right-wing People's Party (PP) — with a majority in congress at the time - to pass that law proposal, and that the PAH's year and half long campaign to collect nearly a million and a half signatures backing up its legislative petitionthree times the amount needed for a citizen-led law proposal—was more about disseminating the PAH message than about changing a law.

For all PAH activists, the tactics and methods used by the PAH were a way of fighting an unfair and unjust system that sought to speculate with housing. Though all would have agreed on disobeying unfair laws by resisting evictions and recuperating buildings in the hands of rescued banks, the extent to which the PAH should self-manage buildings recuperated from banking institutions or turn them over to the administration by forcing their reconversion into housing units was a matter of heated debate. There is no unique view within the PAH of how to move forward with a movement that has been incredibly successful in gathering tens of thousands of people to meet weekly and discuss housing access. For some critical leftist voices - mostly outside the movement - the demands and actions the PAH has put forward can only be considered a reform to the current economic system. For others, like Albert Jimenez (2013), at the PAH people have learnt to act against injustice beyond what is deemed legal or illegal (civil disobedience), the movement has consolidated a real working-class participation (working class understood in its broadest sense ${ }^{15}$ ) where change has happened in the form of debt forgiveness but also in the ideological conceptualizations people held of debt and occupation. The PAH has also created new communities of social cohesion that go beyond traditional labor issues and productive work but also beyond housing. For instance, at the PAH, new forms of relating have formed that have successfully dealt with racism at a time of rapid right-wing racist and xenophobic rise in Europe, and traditional gender roles have been questioned-particularly among migrant groups (Suarez 2018). Finally, occupation has become a real - and often the only - form of housing for hundreds of evicted families. This is the case of people like Esther.

Esther, a mid 30s Ecuadorian woman and her two young children, lived for 1 year in one of the PAH's recuperated buildings. Part of the Obra Social campaign, the building belonged to a Spanish credit union that had gone bankrupt during the burst of the housing bubble. The credit union was absorbed by a large Spanish bank after receiving a generous rescue package - or financial incentive as banking institutions sometimes call them - approved by the PP, the same right-wing party that turned down the PAH-sponsored law. Seeing this as a misuse of tax payers money, the PAH initiated a campaign to recover buildings repossessed by banks that had received vast amounts of public funds (and which often sat unused for years), in order to transform them into properties for evicted families with no housing alternative- like Esther and her children. Many of these families were denied housing aids because their salaries were too low, ${ }^{16}$ and found themselves homeless. Given the low amount of social housing units that exist in Spain (less than 1\%), very few families had any housing alternative after eviction. The PAH's campaign was one of the only real solutions many of these families had. At the PAH families that had often dismissed "occupations" as unsanitary, illegal, and substandard,

\footnotetext{
15 Jiménez 2013refers here to moving beyond working-class groups in their traditional sense tied to productive labor by including a vast array of precarious people (students, pensioners, unemployed, temp workers, those precariously employed, etc.).

${ }^{16}$ In order to access certain forms of aid from public administrations people need to be above a certain economic threshold. Many families at the PAH were below this line and thus too poor to qualify for these housing aid. This is also something the PAH has denounced as illogical and nonsensical. In certain municipalities the PAH has been successful in changing these parameters.
} 
holding many common stereotypes about people who occupied, realized that often it is the only form of housing possible and that occupied flats can indeed be homes. As Esther put it, "we might live with the stigma of being okupas [occupiers], but we're also just normal people living in a house, in a community of neighbors who help each other whenever we can."

Looking at this PAH practice of occupying empty buildings for families without housing options, García-Lamarca (2017, 3-4) argues that the Obra Social "has significant emancipatory potential as a political act that disrupts the core dynamics of urban capital accumulation and enacts equality for evicted households faced with a mortgage debt for life, by directly contesting financial rent-extraction mechanisms on multiple levels." Through building recuperation, the PAH has legitimize the appropriation of empty homes to be used by families who had no other housing alternative. In this way, the PAH has been able to build a narrative around occupation that was not there before. Families like Esther's have challenged housing speculation by occupying these properties instead of leaving them empty in the face of homelessness. Along the way, a popular narrative around this practice has built support for the use of empty properties as social housing units under a now commonly heard expression: "It doesn't make sense: homes without people and people without homes. [No s'entén, gent sense casa i cases sense gent]." Thus, through its many campaigns of eviction resistance, demand of debt forgiveness upon repossession, and reoccupation of empty buildings, the PAH has transformed the narrative and practices around housing access gathering support-and activists - from very diverse backgrounds as well as achieving vast popular support for its demands.

\section{Conclusion}

The PAH's appearance in the post-bubble Spanish scene is not an isolated event. From the Indignados or 15M movement in 2011 to a number of Mareas (Tides) that arose in defense of health, education, labor rights, and many others, the PAH stood as the largest housing movement in the country with over 240 chapters across Spain. The PAH was at the forefront of many of these protests but its growth and momentum could not be separated from the many movements protesting against the thinning of an already underdeveloped Spanish welfare system via pro-austerity policies dictated by international creditors (including the European Commission and Central Bank, and the International Monetary Fund). As Susana Narotzky $(2016,82)$ has pointed out many of these mobilizations "rested on concepts of inequality and injustice." This was also the case for the PAH; however, the frantic activity at the PAH, including the near daily direct actions to banks or government institutions, its campaigns to shame politicians (escraches), various citizen-led law proposals at the national and regional level, its reoccupation of empty buildings in the hands of bailed out banks in order to rehouse evicted families, and endless assemblies held weekly at the local level, monthly at the regional level, and biannually at the national level, online and in person; effectively transformed the PAH into a political site from which everyday people were able to challenge the financial system and the government alike.

In this paper, I have argued that these PAH practices and methods can be considered revolutionary. They can be seen in that light if we see them as consisting "above all of planetwide transformations of political common sense" (Graeber 2013). I have argued that debt default is currently being organized at a global level even if still — for the most part — disconnected. This nonetheless points to a growing desire to look for possibilities that can radically transform the spaces 
debt has crept into. Grassroots organizing like the one conducted by the PAH is creatively resisting the advancement of different forms of financial predation while coming up with real solutions for people directly affected by its worst effects. Distinctively diverse groups have come together at the PAH to create new narratives of indebtedness and reimagine life after Spain's housing bubble, even beyond housing access. As many activists within the PAH saw it, organized mortgage default, pressuring banks for debt forgiveness, reoccupying buildings, and transforming flats in the hands of rescued banks, all have the ability of pushing the boundaries of how every day people think about housing access.

Many scholars have pointed to credit-debt relations in current times as relevant starting points for a renewed anthropological critique of financial capitalism as well as for rethinking our democratic demands and actions (Meister 2016; Martin 2016; Núñez 2017). Credit-debt relations - and especially resistance to indebtedness - open up new ways to begin radically transforming these new forms of financial predation. This might not happen in one violent attack or insurgent take over of institutional power, but rather on a daily basis (Gibson-Graham 1996, 264). This is very much what the PAH has been building from below: a resistance to evictions, a daily construction of spaces of encounter, re-signifying debt, reconstructing social ties, and putting forward a citizen-led legislative change to redefine indebtedness and housing access. These might just be our most "revolutionary practices" (Graeber 2011b): daily acts that have already began building revolutionary change. I understand this might not be seen as revolutionary by some, but I want to suggest that this lack of belief in the transformative power of grassroots strategies is a critique directed - not uncommonly from the left - to different social movements that often obscures many of the avenues that these movements do in fact open up for contesting power. As Kate Crehan (2016, 176) emphasized, "perhaps the point is not ows [Occupy Wall Street]'s failure to bring about any lasting change, but its role in bringing to the fore an existing, but suppressed, good-sense understanding of fundamental problems inherent in the current American system." I would like to suggest that the $\mathrm{PAH}$ has, in the case of Spain, been rather successful in bringing to the fore the most violent side of mortgage debts, particularly to low-income families, and it has demonstrated in a number of ways the possibilities that already exist and are being used for exposing, resisting, and countering the complex networks that make up financial predation nowadays.

From the viewpoint of Ecuadorian migrants, the PAH meant a political project sensitive to their transnational needs and aspirations. At the PAH, my interlocutors not only learned practical tools to deal with foreclosure and eviction, they also became aware of the possibility to reimagine their futures after default. The PAH allowed them to see themselves beyond old narratives of proprietorship as the best way of "becoming someone" - as Rodrigo once put it — and instead allowed them to become part of a broader collective where they were not migrants or debtors or low-skill laborers, but compañeras, members of the same social movement for the right to housing. This reminds us that citizenship too is a contested space in global cities, particularly among migrant groups (Lem 2013) and that activism can be one way of redefining it.

Finally, I would like to finish by suggesting that the PAH has shed light into the blind spots of crisis narratives (Roitman 2014) that obliterate the revolutionary potential of organizing against the financial system. Put briefly then, this article has illustrated a series of every day methods and strategies that have not only stopped evictions and canceled thousands of debts in Spain, but have also inspired new ways for accessing housing and imagining the city.

Acknowledgements I would like to thank the families at PAH Barcelona who generously allowed me into their homes and lives. I am grateful to Alpa Shah, Isaac Marrero-Guillamón, and David Graeber for shaping the ideas 
presented in this article. I am indebted to two anonymous reviewers at Dialectical Anthropology for their comments and help in reworking various aspects of this piece and to Alan Klima and Jorge Núñez for detailed readings and suggestions on drafts of the text. I also benefited from feedback provided by participants in a Writing Seminar at the University of California, Davis. Research for this paper was funded by Ecuador's SENESCYT [Secretaría Nacional de Educación Superior, Ciencia, Tecnología e Innovación].

\section{Compliance with ethical standards}

Conflict of interest The author declares that she has no conflict of interest.

\section{References}

Alberto, Acosta, Susana López, and David Villamar. 2005. Las remesas y su aporte para la economía Ecuatoriana. In La migración Ecuatoriana: transnacionalismo, redes e identidades, ed. Giocondaand Alicia Torres Herrera, 227-252. Quito: FLACSO - Sede Ecuador.

Appel, Hannah. 2014. Occupy Wall Street and the Economic Imagination. Cultural Anthropology 29 (4): $602-$ 625. doi:10.14506/ca29.4.02.

Bear, Laura, Karen Ho, Anna Tsing, and Sylvia Yanagisako. 2015. "Gens: A Feminist Manifesto for the Study of Capitalism.” Cultural Anthropology Website, Generating Capitalism,, no. Theorizing the Contemporary (March).

Bloch, Maurice. 2010. Marxism and Anthropology: The History of a Relationship. Anthropology and Ethnography. London: Routledge.

Calero, Carla, Arjun S. Bedi, and Robert Sparrow. 2009. Remittances, Liquidity Constraints and Human Capital Investments in Ecuador. World Development 37 (6): 1143-1154. doi:10.1016/j.worlddev.2008.10.006.

Chomsisengphet, Souphala, and Anthony Pennington-Cross. 2006. "The Evolution of the Subprime Mortgage Market.” Federal Reserve Bank of St. Louis Review, Kansas City, 88 (1): 31-56.

Clover, Joshua. 2011. The Time of Crisis. Online platform for militant research, critical pedagogy, feminism, media interventions, dissent and prefigurative action. Occupy Everything (OE) October 4. http://occupyeverything.org/2011/the-time-of-crisis/.

Colau, Ada, and Adriá Alemany. 2012. Mortgaged Lives: From the Housing Bubble to the Right to Housing. Los Angeles, CA: Journal of Aesthetics \& Protest Press.

Crehan, Kate. 2016. Gramsci’s Common Sense: Inequality and Its Narratives. Durham, NC: Duke University Press.

Diaz-Serrano, Luis, and Josep M. Raya. 2014. Mortgages, Immigrants and Discrimination: An Analysis of the Interest Rates in Spain. Regional Science and Urban Economics 45 (0): 22-32. doi:10.1016/j. regsciurbeco.2013.12.004.

Dimsky, Gary. 2009. Racial Exclusion and the Political Economy of the Subprime Crisis. Historical Materialism 17: 149-179. doi:10.1163/156920609X436162.

García, Marisol. 2010. The Breakdown of the Spanish Urban Growth Model: Social and Territorial Effects of the Global Crisis. International Journal of Urban and Regional Research 34 (4): 967-980. doi:10.1111/j.14682427.2010.01015.x.

García-Lamarca, Melissa. 2017. From Occupying Plazas to Recuperating Housing: Insurgent Practices in Spain. International Journal of Urban and Regional Research, January, n/a-n/a. doi:10.1111/1468-2427.12386.

Gibson-Graham, J.K. 1996. The End of Capitalism (as We Knew It): A Feminist Critique of Political Economy. Cambridge: Blackwell.

Graeber, David. 2011a. Debt: The First 5000 Years. New York: Melville House.

Graeber, David. 2011b. Revolutions in Reverse: Essays on Politics, Violence, Art, Graeber, David.

Graeber, David. 2013. A Practical Utopian's Guide to the Coming Collapse. New York City: The Baffler April. https://thebaffler.com/salvos/a-practical-utopians-guide-to-the-coming-collapse.

Han, Clara. 2012. Life in Debt: Times of Care and Violence in Neoliberal Chile. Berkeley: University of California Press.

Hernandez, Jesus. 2009. Redlining Revisited: Mortgage Lending Patterns in Sacramento 1930-2004. International Journal of Urban and Regional Research 33 (2): 291-313. doi:10.1111/j.1468-2427.2009.00873.x.

Ho, Karen. 2009. Liquidated: An Ethnography of Wall Street. Durham: Duke University Press.

Ho, Karen. 2012. "'Occupy Finance and the Paradox/Possibilities of Productivity.' Theorizing the Contemporary." Cultural Anthropology Website. May 15. https://culanth.org/fieldsights/340-occupy-finance-and-the-paradoxpossibilities-of-productivity.

James, Deborah. 2014. Money from Nothing: Indebtedness and Aspiration in South Africa. Stanford: Stanford University Press.

Jefferson, Anna. 2013. Narratives of Moral Order in Michigan's Foreclosure Crisis. City \& Society 25 (1): $92-$ 112. doi:10.1111/ciso.12006. 
Jiménez, Albert. 2013. La PAH o El Somni de Gramsci [The PAH or Gramsci's Dream]. Rotekeil. April 13. http://rotekeil.com/2013/04/13/la-pah-o-el-somni-de-gramsci-2/.

Knorr-Cetina, Karin, and Preda. 2012. The Oxford Handbook of the Sociology of Finance. Oxford: Oxford University Press.

Laredo, Manuel. 2011. "El modelo inmobiliario español y sus consecuencias.” In El model inmobiliario español y su culminación en el caso valenciano, edited by Manuel Laredo and Antonio Montiel Márquez, 176. Antrazyt. Barcelona: Icaria.

Lazzarato, Maurizio. 2012. The Making of the Indebted Man: An Essay on the Neoliberal Condition. Intervention Series. Los Angeles, CA: Semiotext (e).

Lee, Benjamin, and Randy Martin, eds. 2016. Derivatives and the Wealth of Societies. Chicago: The University of Chicago Press.

Lem, Winnie. 2013. Citizenship, Migration and Formations of Class in Urban France. Dialectical Anthropology 37 (3): 443-461. doi:10.1007/s10624-013-9324-z.

Llonch, Pau. 2013. "Mobilització y revolta [Mobilization and revolt]." presented at the Jornades "Jo em rebel·lo nosaltres existim" [I rebel. We exist], Caldes D’Estrac, November 29. https://vimeo.com/81176561.

López, Isidro, and Emmanuel Rodríguez. 2011. The Spanish Model. New Left Review 69 (May/June): 5-29.

Martin, Randy. 2016. From the Critique of Political Economy to the Critique of Finance. In Derivatives and the Wealth of Societies, 174-198. Chicago: The University of Chicago Press.

Maurer, Bill. 1999. Forget Locke? From Proprietor to Risk-Bearer in New Logics of Finance. Public Culture 11 (2): 365-385. doi:10.1215/08992363-11-2-365.

McClanahan, Annie. 2011. The Living Indebted: Student Militancy and the Financialization of dDebt. Qui Parle: Critical Humanities and Social Sciences 20 (1): 57-77.

Meister, Robert. 2016. Liquidity. In Derivatives and the Wealth of Societies, ed. Benjamin Lee and Randy Martin, 143-173. Chicago: The University of Chicago Press.

Narotzky, Susana. 2016. Between Inequality and Injustice: Dignity as a Motive for Mobilization during the Crisis. History and Anthropology 27 (1): 74-92. doi:10.1080/02757206.2015.1111209.

Núñez, Jorge. 2017. A Clinical Economy of Speculation: Financial Trading and Gambling Disorder in Spain. Cultural Anthropology 32 (2): 268-292. doi:10.14506/ca32.2.08.

Palomera, Jaime. 2014. How Did Finance Capital Infiltrate the World of the Urban Poor? Homeownership and Social Fragmentation in a Spanish Neighborhood. International Journal of Urban and Regional Research 38 (1): 218-235. doi:10.1111/1468-2427.12055.

Riles, Annelise. 2011. Collateral Knowledge: Legal Reasoning in the Global Financial Markets. In Chicago Series in Law and Society. Chicago, Ill: University of Chicago Press.

Roitman, Janet. 2014. Anti-Crisis. Durham, NC: Duke University Press.

Ross, Andrew. 2014. Creditocracy: And the case for debt refusal. New York: OR Books.

Sabaté, Irene. 2016. Mortgage Indebtedness and Home Repossessions as Symptoms of the Financialisation of Housing Provisioning in Spain. Critique of Anthropology 36 (2): 197-211. doi:10.1177/0308275X15614636.

Shah, Alpa. 2014. 'The Muck of the Past': Revolution, Social Transformation, and the Maoists in India. Journal of the Royal Anthropological Institute 20 (2): 337-356. doi:10.1111/1467-9655.12107.

Smith, Gavin. 2016. Against Social Democratic Angst about Revolution: From Failed Citizens to Critical Praxis. Dialectical Anthropology 40 (3): 221-239. doi:10.1007/s10624-016-9421-x.

Stout, Noelle. 2016. Petitioning a Giant: Debt, Reciprocity, and Mortgage Modification in the Sacramento Valley. American Ethnologist 43 (1): 158-171. doi:10.1111/amet.12270.

Strike Debt. 2014. The Debt Resisters' Operations Manual. Oakland: PM Press/Common Notions.

Suarez, Maka. 2017. The Subprime Middle Class: Precarious Labour, Mortgage Default, and Activism among Ecuadorian Migrants in Barcelona. London: Goldsmiths, University of London.

Suarez, Maka. 2018. The Best Investment of Your Life': Mortgage Lending and Transnational Care among Ecuadorian Migrant Women in Barcelona. Journal of the Royal Anthropological Institute.

Tobes, Portillo Paloma, and Miguel Angoitia Grijalba. 2010. "La Cobertura de Los Inmigrantes Ante El Desempleo." Revista ICE.

Tucker, Robert C. 1978. The Marx-Engels Reader. 2d ed. New York: Norton.

Williams, Brett. 2004. Debt for sale: A social history of the credit trap. Philadelphia, PA: University of Pennsylvania Press.

Wosnitzer, Robert. 2016. Mapping the Trading Desk: Derivative Value through Market Making. In Derivatives and the Wealth of Societies, ed. Benjamin Lee and Randy Martin, 252-273. Chicago: The University of Chicago Press.

Yanagisako, Sylvia. 2013. Transnational Family Capitalism: Producing 'Made in Italy' in China. In Vital Relations: Modernity and the Persistent Life of Kinship, 63-84. Santa Fe: SAR Press.

Zaloom, Caitlin. 2006. Out of the Pits: Traders and Technology from Chicago to London. Chicago: The University of Chicago Press. 